\title{
AT-TARBAWI
}

At-Tarbawi: Jurnal Pendidikan, Sosial dan Kebudayaan

Volume 6 Nomor 1 Tahun 2019

doi: 10.32505/tarbawi.v6i1.1031

\section{Penerapan Strategi Pembelajaran Aktif untuk Meningkatkan Hasil Belajar IPA di MTsN Langsa}

\begin{abstract}
ZAIMAH
Madrasah Tsanawiyah Negeri 1 Langsa

zaimah@gmail.com

Abstract

This study aims to improve student learning outcomes in the field of science studies, the activities carried out in the learning process, by maximizing student activity, the teacher is only as a facilitator and motivator. In learning the teacher uses Active Learning Strategies. Students are expected to have high learning activities so that all the difficulties faced by students can be overcome. The research methodology used was Classroom Action Research (CAR) conducted in 2 cycles. The research subject is class VII4. The data in this study were obtained by test scores and observations. From the results of the learning activities that have been carried out and based on the discussion and analysis that has been carried out, it can be concluded that learning using Active Learning Strategies has a positive impact that can improve student learning outcomes and improve student learning achievement which is marked by increased student mastery in cycle I 6 students or $22.22 \%$ were completed and in the second cycle obtained the value of students who completed following the minimum completeness criteria (KKM 70) of 25 students or 92.59\%. Then it can be concluded that there is an increase in student learning outcomes using Active Learning Strategies for students of class VII - 4 at MTs Langsa.
\end{abstract}

Keywords: Active Learning Strategy, Learning Outcomes, Science

\begin{abstract}
Abstrak
Penelitian ini bertujuan untuk meningkatkan hasil belajar siswa dalam bidang studi IPA, kegiatannya dilaksanakan dalam proses pembelajaran, dengan memaksimalkan keaktifan siswa, guru hanya sebagai fasilitator dan motifator. Dalam pembelajaran guru menggunakan Strategi Pembelajaran Aktif. Siswa diharapkan memiliki aktifitas belajar yang tinggi sehingga segala kesulitan yang di hadapi siswa dapat teratasi. Metodologi penelitian yang digunakan Penelitian Tindakan Kelas (PTK) yang dilaksanakan dalam 2 siklus. Subjek penelitiannya kelas VII4. Adapun data dalam penelitian ini diperoleh dengan nilai tes dan observasi. Dari hasil kegiatan pembelajaran yang telah dilakukan dan berdasarkan pembahasan serta analisis yang telah dilakukan dapat disimpulkan bahwa pembelajaran menggunakan Strategi Pembelajaran Aktif memiliki dampak positif yaitu dapat meningkatkan hasil belajar siswa dan meningkatkan prestasi belajar siswa yang ditandai dengan peningkatan ketuntasan belajar siswa dalam siklus I 6 siswa atau 22,22\% yang tuntas dan pada siklus dua diperoleh nilai siswa yang berhasil tuntas sesuai dengan kriteria ketuntasan minimal (KKM 70) sebesar 25 siswa atau 92,59\%. Maka dapat disimpulkan adanya peningkatan hasil belajar siswa menggunakan Strategi Belajar Aktif pada siswa kelas VII-4 di MTs Negeri Langsa.
\end{abstract}

Kata kunci: Strategi Pembelajaran Aktif, Hasil belajar, IPA 


\section{A. Pendahuluan}

Pelaksanaan pengajaran yang dilakukan perlu adanya penelitian agar didapatkan pengajaran yang paling efektif untuk digunakan baik pada kesempatan yang sekarang maupun yang akan datang. Pada kesempatan ini peneliti mengadakan penelitian tentang hasil belajar gerak siswa kelas VII-4 melalui strategi pembelajaran aktif, dan yang menjadi fokus pada penelitian ini adalah hasil belajar siswa selama penerapan pembelajarn aktif yang dilakukan oleh guru dalam mengajarkan materi belajar gerak tersebut. Tidak efektifnya pengajaran yang dilakukan guru tersebut diduga akibat kurang tepatnya guru dalam menggunakan strategi pembelajaran. Hal ini ditandai adanya kecenderungan guru dalam mengajarkan materi tersebut dengan metode ceramah secara klasikal. Dilandasi keinginan untuk mencari strategi pembelajaran yang tepat dan efisien untuk meningkatkan hasil nilai belajar gerak pada MTs Negeri Langsa, maka peneliti merasa perlu mengadakan penelitian tindakan kelas ini.

Peningkatan hasil belajar pada materi belajar gerak dan efektifitas pembelajaran yang diharapkan oleh peneliti adalah dengan langkah mengarahkan pembelajaran siswa aktif secara kelompok besar maupun dalam kelompok kecil. Selain harapan yang telah disampaikan diatas penelitian ini diharapkan dapat merubah paradigma guru dalam melakukan pembelajaran dari guru sebagai pusat belajar agar beralih ke siswa. Guna mewujudkan harapan yang diinginkan oleh peneliti seperti di atas maka peneliti menerapkan strategi pembelajaran aktif dengan menggunakan teknik strategi pembelajaran aktif untuk peningkatan hasil belajar siswa dalam materi Gerak. Pada setiap pengajaran ada tujuan yang harus dicapai dan untuk pencapaian tujuan tersebut kita perlu menyampaikan topik - topik yang didalamnya ada konsep-konsep yang harus sampai pada siswa, dan untuk itu diperlukan pendekatan tertentu seperti pemecahan masalah, latihan soal, latih - hafal dan mungkin dengan pendekatan yang lainnya. 
Andi Hakim Nasution (1988:243) menyatakan bahwa dalam suatu pengajaran yang berkaitan dengan suatu materi kurikulum tertentu prinsip keterlaksanaan dipenggaruhi oleh empat komponen pokok yaitu pembawa materi, penyaji materi, pendekatan dan penerima materi. Pengaturan materi kurikulum tersebut dinamakan strategi belajar mengajar. Pada pengajaran IPA sampai sekarang ini masih menggunakan strategi belajar mengajar langsung dan sempit. Maksudnya adalah materi pelajaran yang dibawakan guru itu sempit (dikumpulkan oleh guru itu sendiri), penyajinya guru itu sendiri pendekatan yang digunakan deduktif dan siswa yang menerimanya adalah kelompok besar, padahal bila dilihat dari kombinasi yang ada dalam strategi pembelajaran paling tidak ada 81 kombinasi yang dapat dilaksanakan dalam pengajaran.

Aktifitas siswa belajar di kelas terwujud bila terjadi interaksi antar warga kelas. Boakes dalam Mar'at (1984:46) menyatakan bahwa di dalam interaksi ada aktifitas yang bersifat resiprokal (timbal balik) dan berdasarkan atas kebutuhan bersama, ada aktifitas daripada pengungkapan perasaan, dan ada hubungan untuk tukar-menukar pengetahuan yang didasarkan take and give, yang semuanya dinyatakan dalam bentuk tingkah laku dan perbuatan. Lebih lanjut, Syamsu Mappa (1994:46) menyatakan hubungan timbal balik antar warga kelas yang harmonis dapat merangsang terwujudnya masyarakat kelas yang gemar belajar.

Dengan demikian, upaya mengaktifkan siswa belajar dapat dilakukan dengan mengupayakan timbulnya interaksi yang harmonis antar warga di dalam kelas. Interaksi ini akan terjadi bila setiap warga kelas melihat dan merasakan bahwa kegiatan belajar tersebut sebagai sarana memenuhi kebutuhannya. Dalam kaitannya dengan proses pembelajaran, berdasarkan teori kebutuhan Maslow, Silberman (2006:30) menyatakan kebutuhan akan rasa aman harus dipenuhi sebelum bisa dipenuhinya kebutuhan untuk mencapai sesuatu, mengambil resiko, dan menggali hal-hal baru. 
Dari pembahasan di atas, tip-tip dibawah ini dapat digunakan guru untuk mengarah pada strategi pembelajaran yang dapat mengaktifkan siswa dalam belajar:

1) Selalu berpenampilan menarik dan penuh wibawa.

Kesan pertama siswa saat bertemu gurunya adalah fisik dari guru tersebut. dengan penampilan yang menarik dan penuh wibawa akan membuat kesan yang positif dari siswa, sehingga dengan mudah guru akan dapat membawa siswa kedalam suasana belajar yang guru inginkan.

a) Manfaatkan pertemuan pertama dengan siswa untuk perkenalan antar warga kelas, tunjukkan cara-cara belajar IPA yang baik, buatlah kesepakatan (kontrak) terkait norma-norma yang harus dipatuhi oleh warga kelas.

b) Buatlah formasi tata letak meja, kursi, pajangan dinding, dan perabot kelas yang lain sesuai dengan kesepakatan warga kelas dan kebutuhan.

c) Siapkan semua peralatan yang akan digunakan di dalam ruang kelas sebelum memulai pembelajaran.

d) Mulailah proses belajar mengajar dengan materi yang ringan tetapi menantang yang dapat merangsang siswa turut aktif berfikir. Kemudian masuk pada materi yang akan kita ajarkan dengan senantiasa melibatkan siswa dalam proses belajar mengajar. Misalkan senantiasa mengajukan pertanyaanpertanyaan tentang materi yang kita ajarkan agar siswa lebih mudah memahami materi yang kita berikan.

e) Selalu memulai dan mengakhiri pembelajaran tepat waktu serta dengan salam yang menghangatkan, yaitu salam penuh kasih dan hormat.

f) Gunakan bahasa yang santun, hormat, dan dengan nada bicara yang lembut.

g) Memahami dan menghormati berbagai perbedaan yang ada.

h) Menghormati kerahasiaan setiap siswa

i) Tidak merendahkan dan mencemooh siswa 
j) Memberi kesempatan yang sama kepada semua siswa untuk bicara dan jangan mengintrupsi pembicaraan siswa

k) Bila seorang siswa mengemukakan pendapat, jadilah pendengar yang baik dan selanjutnya berikan kesempatan kepada siswa lain untuk memahaminya dan memberikan komentarnya.

l) Memahami dan menghormati pendapat setiap siswa, bila perlu melancarkan kritik: gunakan bahasa yang mengayomi, dan bila kritik bersifat pribadi seyogyanya dilakukan di ruang khusus.

m) Sekali waktu, berilah kesempatan kepada siswa untuk memberikan saran atau kritik guna perbaikan proses pembelajaran.

n) Sediakan waktu untuk berkomunikasi dengan siswa di luar kelas.

Proses pembelajaran di kelas dapat dipandang sebagai tiga bagian kegiatan yang terurut, yaitu: kegiatan awal (pendahuluan), kegiatan inti, dan kegiatan akhir (penutup). Dengan demikian, strategi pembelajaran aktif dapat dirumuskan sebagai prosedur kegiatan yang mengaktifkan siswa pada setiap bagian kegiatan secara terurut. Prosedur tersebut dapat dirumuskan sebagai berikut:

1) Prosedur Mengaktifkan Siswa Belajar IPA Pada Awal Pembelajaran. Dimensi pertama dalam peristiwa belajar IPA adalah membangun sikap dan persepsi positif terhadap belajar dan IPA sebagai obyek belajar. Kesiapan mental untuk terlibat dalam pembelajaran mutlak dicapai dalam mengaktifkan siswa belajar IPA, oleh karenanya kegiatan membangunkan sikap dan persepsi positif siswa harus dilakukan sejak awal dimulainya pembelajaran. Hal yang harus dilakukan guru pada awal pembelajaran adalah membangunkan minat, membangunkan rasa ingin tahu, dan merangsang siswa untuk berfikir. Bila minat siswa, rasa ingin tahu siswa telah bangkit, serta siswa telah terangsang untuk berfikir ini berarti siswa telah siap secara mental untuk terlibat secara aktif dalam pembelajaran IPA, dan bila terjadi sebaliknya berarti secara mental siswa belum siap terlibat dalam pembelajaran. Dengan memodifikasi strategi 
berbagi pengetahuan secara aktif, Silberman (2006:100) mengawali kegiatan pembelajaran aktif dengan prosedur sebagai berikut:

a) Tentukan rentang waktu yang pasti untuk kegiatan awal pembelajaran.

b) Ucapkan salam pembuka yang menghangatkan siswa.

c) Sediakan daftar pertanyaan yang terkait dengan materi pelajaran IPA yang akan diajarkan. Misalnya:

(1) Mendeskripsikan pengertian dasar gerak,

(2) Mendeskripsikan pengertian gerak cepat,

(3) Pertanyaan tentang aplikasi IPA sederhana dalam kehidupan sehari-hari.

d) Perintahkan siswa untuk menjawab pertanyaan-pertanyaan itu sebaik yang mereka bisa dan dalam waktu yang telah ditentukan.

e) Perintahkan siswa untuk menyebar di kelas, menanyakan kepada temannya jawaban pertanyaan yang dia sendiri tidak tahu jawabannya, Doronglah siswa untuk saling membantu.

f) Perintahkan untuk kembali ke tempat semula dan gunakan teknik tanya jawab untuk membahas jawaban yang mereka dapatkan.

g) Gunakan pertanyaan-pertanyaan arahan sebagai upaya merangsang berfikir siswa menjawab pertanyaan yang tak satupun siswa bisa menjawab.

h) Gunakan informasi-informasi yang diperoleh dalam kegiatan ini sebagai sarana untuk memperkenalkan topik-topik penting materi pelajaran dalam kegiatan inti.

Secara umum, manusia tidak menyukai suatu kegiatan yang kurang bervariasi. Oleh karenanya perlu dipilih kegiatan lain sebagai variasi kegiatan di atas. Berikut ini dapat menjadi alternatif pilihan.

a) Daftar pertanyaan dapat diganti dengan menyediakan kartu indeks dan perintahkan siswa untuk menuliskan satu informasi yang menurut siswa akurat tentang materi yang akan diajarkan. 
b) Kegiatan menyebar dapat diganti dengan merotasi pertukaran pendapat antar kelompok belajar di kelas.

2) Prosedur Mengaktifkan Siswa Belajar IPA Pada Kegiatan Inti Pembelajaran

Telah dikemukakan di atas bahwa pendidikan IPA di segala jenjang dimaksudkan untuk membangun pengetahuan, keterampilan dan sikap terkait dengan IPA. Pembelajaran aktif dalam pendidikan IPA dapat berlangsung dalam proses penyelidikan atau proses bertanya. Siswa dikondisikan dalam sikap mencari (aktif) bukan sekedar menerima (reaktif). Kondisi ini terjadi jika siswa dilibatkan dalam tugas dan kegiatan yang secara halus mendesak mereka untuk berfikir, bekerja, dan merasakan.

Berdasarkan pendapat di atas, upaya yang harus dilakukan guru untuk mengaktifkan siswa belajar IPA adalah: (1) mengkondisikan situasi belajar IPA menjadi kegiatan siswa mengupayakan pemecahan masalah atau mencari jawaban atas pertanyaan-pertanyaan, baik masalah atau pertanyaan yang diajukan guru maupun siswa; (2) mendorong ketertarikan siswa untuk mendapatkan informasi atau menguasai keterampilan melalui pemecahan masalah atau mencari jawaban atas pertanyaan; (3) mendesak siswa secara halus untuk bergerak mengkaji atau menilai suatu jawaban pertanyaan, suatu pendapat (gagasan), atau suatu penyelesaian masalah. Guru dapat menggunakan berbagai strategi dengan berbagai teknik untuk mengaktifkan siswa dalam kegiatan inti. Dengan memodifikasi pendapat Silberman (2006:117) .

3) Strategi menutup pembelajaran IPA

Pada kegiatan menutup pembelajaran dapat dimanfaatkan guru untuk:

a) memberikan kesempatan bagi siswa merangkum atau membuat ikhtisar dari pelajaran pada hari itu,

b) memotivasi siswa untuk mempelajari ulang bahan ajar dan atau menyelesaikan tugas rumah secara mandiri atau kelompok,

c) memberikan informasi bahan ajar pertemuan berikutnya, 
d) mendapatkan penilaian dari siswa guna perbaikan proses pembelajaran, dan

e) memberikan salam penutup.

\section{B. Metode}

Penelitian tindakan kelas ini dilaksanakan dengan mengambil lokasi di MTs Negeri 1 Langsa. Penelitian tindakan kelas ini dilaksanakan dari bulan Februari tahun 2014 sampai dengan bulan Mei tahun 2014, menggunakan jenis perlakuan tindakan kelas (class room action research) dengan menggunakan 2 siklus. Subyek pada penelitian ini adalah siswa kelas VII ${ }^{4}$ MTS Negeri Langsa, jumlah siswa didalam kelas adalah 27 siswa terdiri dari berbagai macam status sosial. Pelaksanaan penelitian ini melibatkan 1 orang rekan guru sebagai pengamat terhadap aktivitas dan kegiatan pengelolaan pembelajaran yang dilakukan oleh guru. Adapun keempat tahapan pelaksanaan penelitian tindakan kelas adalah (Action Recearch) sebagai berikut:

a. Rencana : Tindakan apa yang akan dilakukan untuk memperbaiki, meningkatkan atau perubahan perilaku dan sikap sebagai solusi.

b. Tindakan : Apa yang dilakukan oleh guru atau peneliti sebagai upaya perbaikan, peningkatan atau perubahan yang diinginkan.

c. Observasi : Mengamati atas hasil atau dampak dari tindakan yang dilaksanakan atau dikenakan terhadap siswa.

d. Refleksi : Peneliti mengkaji, melihat dan mempertimbangkan atas hasil atau dampak dari tindakan dari berbagai kriteria.

Dalam penelitian ini yang akan dilihat indikator kinerjanya. Dan indikator yang diharapkan dalam penelitian tindakan kelas ini adalah:

1. Terjadi peningkatan hasil belajar siswa dan mencapai ketuntasan belajar.

2. Terjadi peningkatan aktivitas belajar siswa pada setiap siklus.

3. Terjadi peningkatan pelaksanaan proses belajar mengajar yang diselenggarakan oleh guru. 
Dalam penelitian tindakan kelas ini dalam teknik pengumpulan data digunakan berbagai tehnik antara lain :

1) Teknik Pengumpulan Data

a. Tes Tertulis

Tes tertulis disini digunakan untuk mengumpulkan data siswa berkenaan hasil pengusaan materi gerak yang dikuasai siswa, setelah siswa mengikuti suatu proses perlakuan yang dilakukan oleh peneliti, sehingga didapatkan hasil yang akurat dan dapat menggambarkan secara jelas kemampuan siswa dalam menguasai materi gerak tersebut.

b. Observasi

Observasi digunakan pada saat pelaksanaan penelitian tindakan kelas. Kemampuan memahami materi gerak pada siklus I, II.

2) Alat Pengumpulan Data

Alat pengumpulan data meliputi :

a. Instrumen Tes secara tertulis terdiri dari 5 butir soal

b. Observasi meliputi lembar observasi dan dokumen siswa.

Validasi data meliputi validasi Hasil Belajar dan Validasi Proses Pembelajaran.

1) Hasil Belajar (Nilai Tes). Validasi hasil belajar dikenakan pada instrumen penelitian yang berupa tes. Validasi ini meliputi validasi teoretis dan validasi empiris. Validasi teoretis artinya mengadakan analisis instrumen yang terdiri atas face validity (tampilan tes), content validity (validitas isi) dan construct validity (validitas kostruksi). Validitas empiris artinya analisis terhadap butir-butir tes, yang dimulai dari pembuatan kisi-kisi soal, penulisan butir-butis soal, kunci jawaban dan kriteria pemberian skor.

2) Validasi Proses Pembelajaran. Validasi proses pembelajaran dilakukan dengan teknik triangulasi yang meliputi yaitu triangulasi sumber dan triangulasi metode. Triangulasi sumber dilakukan dengan observasi terhadap subyek penelitian yaitu siswa kelas VII ${ }^{4}$ MTS Negeri Langsa. 
Triangulasi metode dilakukan dengan penggunaan metode dokumentasi selain metode observasi. Metode dokumentasi digunakan untuk memperoleh data pendukung yang diperlukan dalam proses pembelajaran IPA.

Analisis data yang digunakan dalam penelitian ini adalah teknik analisis deskriptif, yang meliputi :

a) Analisis deskriptif komparatif hasil belajar dengan cara membandingkan hasil belajar sisiwa pada siklus I dengan siklus II.

b) Analisis deskriptif kualitatif hasil observasi dengan cara membandingkan hasil observasi dan refleksi pada siklus I dan siklus II.

\section{Hasil dan Pembahasan}

\section{Deskripsi Kondisi Awal}

Proses belajar mengajar pada mata pelajaran IPA di kelas VII ${ }^{4}$ MTS Negeri Langsa, sebelum pelaksanaan tindakan kelas guru mengajar secara konvensional. Guru cenderung mentransper ilmu kepada siswa, sehingga siswa hanya mendengar dan siswa kurang aktif bahkan cenderung bosan. Proses pembelajaran tampak kaku karena siswa hanya melihat dan mendengar apa yang dijelaskan gurunya. Itu semua berdampak pada hasil nilai siswa di kelas VII ${ }^{4}$ MTS Negeri Langsa khususnya materi gerak. Siswa yang lulus pada materi gerak hanya 3 siswa dari 27 siswa keseluruhannya.

\section{Hasil Penelitian Siklus I}

Berdasarkan hasil penelitian pada siklus I diperoleh nilai siswa yang berhasil tuntas sesuai dengan kriteria ketuntasan minimal (KKM 70), 6 siswa $(22,22 \%)$ tuntas, dan 21 siswa $(77,78 \%)$ tidak tuntas. Hal ini terjadi karena masih banyak siswa yang belum menguasai materi. Berdasarkan hasil observasi peneliti dan pengamat atas hasil kemampuan siswa, maka peneliti dan pengamat kembali merencanakan untuk melanjutkan pada tindakan siklus II dengan terlebih dahulu melakukan perbaikan. Dengan demikian, 
maka direncanakan pada Siklus II ini penerapan strategi pembelajaran aktif dilaksanakan lebih terarah lagi supaya hasil dicapai juga lebih optimal.

\section{Hasil Penelitian Siklus II}

Pada Siklus II, kemampuan siswa mengalami peningkatan, jumlah siswa yang tuntas meningkat yaitu sebanyak 25 siswa (92,59 \%) sedangkan yang tidak tuntas hanya 2 siswa $(7,41 \%)$. Hasil tersebut dapat dikatakan bahwa hasil belajar siswa sudah baik karena ada peningkatan, hal ini menunjukkan perubahan langkah pembelajaran yang digunakan oleh guru cukup efektif dalam memotivasi siswa untuk lebih berani berpendapat. Tingkat kinerja aktivitas guru semakin baik, walaupun masih ada beberapa kekurangan.

Dalam hal ini terlihat secara langsung situasi belajar yang aktif, kreatif, antusias siswa dalam belajar dan memperhatikan serta menyampaikan hasil kerjanya sangat baik, hampir seluruh kelompok mampu menguasai dan aktif dalam proses pembelajaran tersebut. Agar lebih jelas gambaran perbandingan peningkatan hasil kemampuan dari kondisi awal, Siklus I dan Siklus II, dapat dilihat dan diperhatikan pada rekapitulasi tabel dan grafik di bawah ini.

Tabel 1 Rekapitulasi Ketuntasan Belajar Setiap Siklus

\begin{tabular}{|l|l|l|l|l|l|l|l|l|l|l|}
\hline \multirow{2}{*}{ No } & \multirow{2}{*}{ kriteria } & \multicolumn{3}{|c|}{ kondisi awal } & \multicolumn{3}{c|}{ siklus I } & \multicolumn{3}{c|}{ siklus II } \\
\cline { 3 - 11 } & & Jlh & Kat & $\%$ & Jlh & Kat & $\%$ & Jlh & Kat & $\%$ \\
\hline 1 & Nilai $\geq 70$ & 3 & T & 11,11 & 6 & T & 22,22 & 25 & T & 92,59 \\
\hline 2 & Nilai $\leq 70$ & 24 & TT & 88,89 & 21 & TT & 77,78 & 2 & TT & 7,41 \\
\hline \multicolumn{2}{|l|}{ Jumlah } & 27 & 100 & 27 & 100 & 27 & & 100 \\
\hline
\end{tabular}




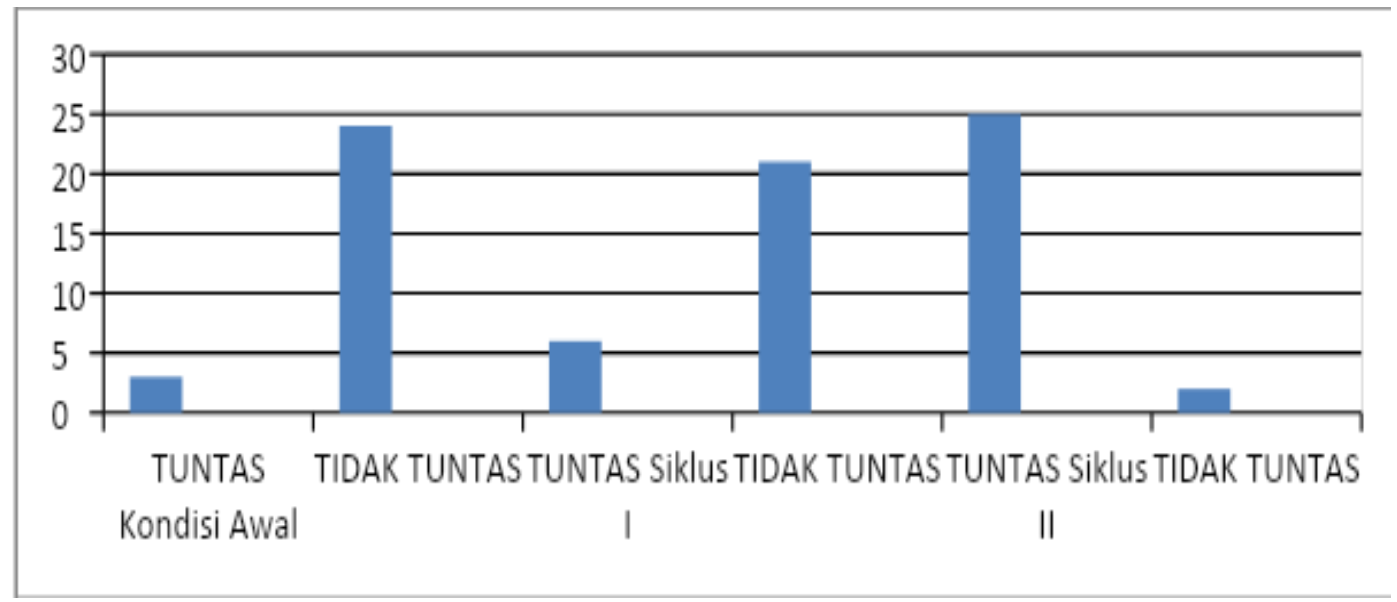

Gambar 1. Ketuntasan Siswa

Berdasarkan hasil penelitian pada siklus I hanya 6 siswa $(22,22 \%)$ yang tuntas, dan pada siklus II diperoleh nilai siswa yang berhasil tuntas sesuai dengan kriteria ketuntasan minimal (KKM 70) sebesar 25 siswa atau 92,59 \% yang tuntas. Hasil tersebut mengindikasikan bahwa rasa takut salah dan malu untuk bertanya sudah berkurang. Siswa sudah mulai mau berbagi kepada teman-temannya. Bahkan mereka juga sudah berani mengajukan saran atau mengomentari pendapat temannya yang keliru. Kalau diperhatikan tiap aktivitas, memang peningkatannya tidak seberapa besar. Tetapi kalau dilihat dari pengelompokan partisipasi aktif dan pasif, prosentase tersebut cukup cukup besar.

Berdasarkan hasil penelitian dapat ditarik kesimpulan adanya peningkatan hasil belajar siswa pada materi gerak menggunakan pembelajaran aktif pada siswa kelas VII ${ }^{4}$ di MTS Negeri Langsa, peningkatan hasil belajar terjadi karena guru menggunakan pembelajaran aktif dalam menyajikan materi gerak dan menyesuaikan langkah-langkah kerja dalam penyusunan rencana pelaksanaan pembelajaran. Dengan menggunakan pembelajaran aktif materi yang ingin dipelajari siswa tidak hanya dilihat dan didengar tapi lebih dari itu. 


\section{Kesimpulan}

Dari hasil kegiatan pembelajaran yang telah dilakukan dan berdasarkan pembahasan serta analisis yang telah dilakukan dapat disimpulkan bahwa penggunaan pembelajaran aktif memiliki dampak positif yaitu dapat meningkatkan hasil belajar siswa dan meningkatkan prestasi belajar siswa yang ditandai dengan peningkatan ketuntasan belajar siswa dalam siklus I yaitu 6 siswa atau 22,22\% yang tuntas. Selanjutnya pada siklus II diperoleh hasil yang memuaskan karena 25 siswa atau 92,59\% berhasil mendapatkan nilai sesuai dengan yang diharapkan untuk nilai KKM 70, Maka dapat disimpulkan adanya peningkatan hasil belajar siswa pada materi gerak menggunakan pembelajaran aktif pada siswa kelas VII ${ }^{4}$ di MTS Negeri Langsa.

\section{UCAPAN TERIMA KASIH}

Penulis mengucapkan terima kasih kepada kepala sekolah, guru, stff serta siswa dan siswi MTS Negeri Langsa yang telah memberi dukungan terhadap penelitian ini.

\section{DAFTAR PUSTAKA}

Ahmad Kosasih Djahiri. 1995/1996. Dasar-dasar Umum Metedologi dan Pelajaran Nilai dan Moral PVCT. Purwakarta IKIP

Andi Hakim Nasution. 1988. Landasan Matematika.Bhratara Karya Aksara, Jakarta.

Arikunto, S. dkk., 1996, Penelitian Tindakan Kelas, Bumi Aksara, Jakarta.

Daniel Muijs dan David Reynolds 2008. Effective Teaching Teori dan Aplikasi (Edisi ke-2) ,Pustaka Pelajar, Yogyakarta.

Hisyam Zaini, Bermawy Munthe \& Sekar Ayu Aryani, 2007. Strategi Pembelajaran Aktif, Pustaka Insan Madani, Jogjakarta.

Mar'at.1984. Sikap Manusia Perubahan serta Pengukurannya. Ghalia Indonesia, Jakarta.

Melvin L. Silberman, 2006. Active learning 101 Cara Belajar siswa aktif, 
Nuansa, Bandung.

Milas, 1992. Metodologi Penelitian Pendidikan. SIC (Surabaya Intellectual Club), Surabaya.

Purwanto, Ngalim. 2008, Psikologi Pendidikan Remaja.Rosdakarya. Bandung.

Sugihartono, dkk. 2007. Psikologi Pendidikan. UNY Press, Yogyakarta

Syamsu Mappa \& Basleman, Anisah, 1994. Teori Belajar Orang Dewasa,. Departemen Pendidikan dan Kebudayaan. Jakarta.

Udin S. Winataputra, 1997. Tita Rosita. Belajar dan Pembelajaran. Depdikud Dirjend. Dikdasmen, Jakarta.

Winkel, W.S. 1983. Psikologi Pengajaran. PT. Gramedia Widia Sarana Indonesia. Jakarta. 